\title{
Pendekatan FMEA dalam Analisa Risiko Perawatan Sistem Bahan Bakar Mesin Induk: Studi Kasus di KM. Sidomulyo
}

\author{
Rizqi llmal Yaqin ${ }^{1 *}$, Zamri' $^{2}$, Juniawan Preston Siahaan ${ }^{3}$, Yuniar Endri Priharanto ${ }^{4}$, M. \\ Subroto Alirejo ${ }^{5}$, Mega Lazuardi Umar ${ }^{6}$ \\ 1,2,3,4) Politeknik Kelautan dan Perikanan Dumai, Program Studi Permesinan Kapal \\ Jl. Wan Amir No.1, Pangkalan Sesai, Dumai 28826 \\ E-mail: 1)r.ilmalyaqin@politeknikkp.dumai, ${ }^{2}$ preston_siahaan@yahoo.com, ${ }^{3}$ zamri09@gmail.com, ${ }^{4 j}$ joeniar@gmail.com \\ ${ }^{5)}$ Sekolah Tinggi Perikanan, Program Studi Permesinan Perikanan \\ Jl. AUP No.1, Pasar Minggu, Jakarta Selatan 12520 \\ E-mail: 5)aliredjo@yahoo.com \\ 6) Fakultas Teknik, Program Studi Teknik Mesin, Universitas Muhammadiyah Jember \\ Jl. Karimata No. 49 Jember 68121 \\ E-mail: 6)megalazuardi@unmuhjember.ac.id
}

\begin{abstract}
The fuel system is one of the main engine support systems which is very important in the operation of the KM Sidomulyo main engine. Main engine on ships are operated 24 hours a week or more. The operation main engine needs special treatment of the components on the main engine to prevent failure during operation. Failure Mode and Effect Analysis (FMEA) is a method that can be used to identify the priority scale in maintaining a machine by evaluating the risk of failure that occurs on the machine. This study applies FMEA to determine the priority scale for the maintenance of the KM Sidomulyo main engine fuel system. The results of the identification using FMEA, namely the injector and fuel filter components are components that must be prioritized for maintenance. The Risk Priority Number (RPN) values of the injector and fuel filter components are 192 and 168, respectively. Maintenance priority is based on the component RPN value is above the critical RPN value of the main engine fuel system and includes the priority component on the Pareto diagram. The type of maintenance applied to the injector component is checking dirty fuel which can cause the injector to operate less optimally. While the fuel filter component is cleaning the deposits on the fuel filter cartridge. It is recommended that the inspection of other components be carried out so that the condition of the main engine fuel system has good reliability.
\end{abstract}

Keywords: Maintenance, FMEA, Fuel System, RPN

\begin{abstract}
Abstrak
Sistem bahan bakar merupakan salah satu sistem pendukung mesin induk yang sangat penting dalam pengoperasian mesin induk KM Sidomulyo. Mesin induk pada kapal dioperasikan selama 24 jam dalam seminggu atau lebih. Pengoperasian mesin induk menyebabkan perlunya perlakuan khusus terhadap komponen-komponen yang ada pada mesin induk untuk mencegah kegagalan saat beroperasi. Failure Mode and Effect Analysis (FMEA) merupakan salah satu metode yang dapat digunakan untuk mengidentifikasi skala prioritas dalam perawatan sebuah mesin dengan mengevaluasi risiko kegagalan yang terjadi pada mesin tersebut. Penelitian ini mengaplikasikan FMEA untuk menentukan skala prioritas pada perawatan sistem bahan bakar mesin induk KM Sidomulyo. Hasil dari identifikasi perawatan menggunakan FMEA yaitu komponen injektor dan saringan bahan bakar menjadi komponen yang harus diprioritaskan perawatannya. Nilai Risk Priority Number (RPN) dari komponen injektor dan saringan bahan bakar secara berturut-turut yaitu 192 dan 168. Prioritas perawatan didasarkan karena nilai RPN komponen di atas nilai RPN kritis sistem bahan bakar mesin induk serta termasuk komponen yang diprioritaskan pada diagram pareto. Jenis perawatan yang diterapkan untuk komponen injektor yaitu pemeriksaan bahan bakar yang kotor yang dapat menyebabkan injektor kurang maksimal beroperasi. Sedangkan komponen saringan bahan bakar yaitu pembersihan endapan pada catridge saringan bahan bakar. Pemeriksaan komponen lain dianjurkan tetap dilakukan agar kondisi sistem bahan bakar mesin induk memiliki keandalan yang baik.
\end{abstract}


Kata kunci: Perawatan, FMEA, Sistem Bahan Bakar, RPN

\section{Pendahuluan}

Indonesia merupakan negara maritim yang memiliki wilayah laut mencapai $5,9 \mathrm{~km}^{2}$ berdasarkan data UNCLOS (Lasabuda, 2013). Data tersebut menyatakan bahwa Indonesia memiliki potensi sumber daya laut yang melimpah. Perlu adanya kapal perikanan dalam pemanfaatan sumber daya perikanan di laut oleh nelayan. Kapal perikanan merupakan salah satu kapal yang digunakan nelayan untuk melakukan operasi penangkapan ikan (Kusdiantoro et al., 2019). Kondisi kelayakan kapal ikan di Indonesia sering tidak diperhatikan oleh pemiliknya salah satunya kelayakan teknis yang dapat menyebabkan risiko kecelakaan saat beroperasi (Sasmita et al., 2013). Beberapa kelayakan teknis operasional kapal yang perlu diperhatikan meliputi ukuran kapal, mesin kapal dan anak buah kapal (Amry et al., 2017). Mesin kapal memiliki peran yang vital di kapal dari segi teknis operasionalnya karena sebagai penggerak kapal ikan saat beroperasi. Mesin kapal ikan banyak menggunakan jenis mesin diesel.

Mesin diesel atau motor diesel merupakan salah satu mesin yang digunakan sebagai mesin induk. Penggunaan mesin diesel pada mesin induk dikarenakan mesin diesel memiliki ketahanan dan efektivitas yang baik saat dioperasikan dengan rentang waktu yang lama dalam operasi penangkapan ikan (Latif et al., 2018). Kinerja mesin diesel sebagai mesin induk kapal dapat berfungsi dengan baik jika didukung dengan sistem penunjang (Nusantara, 2015). Sistem penunjang mesin induk yaitu sistem bahan bakar (fuel oil system) (Alwi, 2016), sistem pelumasan (lubricating system) (Manalu et al., 2016), sistem pendinginan (cooling system) dan sistem start (starting system) (Nusantara, 2015). Salah satu sistem penunjang yang terpenting adalah sistem bahan bakar (Islam et al., 2019). Sistem bahan bakar merupakan salah satu sistem penunjang mesin induk untuk kelancaran operasional sistem penggerak kapal (Hadi \& Untung, 2008). Sistem bahan bakar memiliki peran sebagai penyuplai bahan bakar ke mesin induk dari tangki penampungan (storage tank) menuju mesin induk (Main Engine) (Baharuddin, 2016; Imanuell \& Lutfi, 2019).
Pengoperasian mesin induk pada kapal dioperasikan selama 24 jam sehari selama 1 minggu hingga satu bulan (Saputra et al., 2018). Kondisi pengoperasian mesin secara terus menerus menyebabkan penurunan kinerja pada mesin tersebut (Priharanto et al., 2017). Penurunan kinerja mesin secara terus menerus dapat mengakibatkan kegagalan pengoperasian mesin induk. Beberapa kegagalan mesin induk yang fatal yaitu pembakaran kurang sempurna yang menyebabkan kapal berhenti beroperasi di laut (Alhaddad \& Dianta, 2015). Kegagalan mesin induk yang terjadi saat beroperasi di laut dapat mengakibatkan masalah fatal pada kapal dan anggota kapal (Latif et al., 2018). Kegagalan mesin induk yang merupakan sistem penggerak utama kapal dapat menjadikan kecelakaan transportasi laut yang telah terjadi pada MV Bright Field pada tahun 1996 dan MV Planet pada 2012 (Awal \& Hasegawa, 2015). Perhatian khusus pada mesin induk saat beroperasi merupakan langkah awal untuk mencegah kegagalan terjadi. Perawatan merupakan kegiatan yang penting dilakukan untuk mencegah kerusakan suatu mesin (Soewardi \& Wulandari, 2019; Wannawiset \& Tangjitsitcharoen, 2019). Perawatan mesin induk yang dilakukan oleh anggota kapal dapat mengurangi jumlah kegagalan yang terjadi (Handani \& Uchida, 2014). Proses pengambilan keputusan perawatan mesin induk dapat meningkatkan kinerja fungsi dari perawatan tersebut (Artana \& Ishida, 2002).

Reliability Centered Maintenance (RCM) merupakan salah satu metode untuk pemilihan pengambilan keputusan prioritas perawatan pada mesin blow mould pada industri sehingga dapat mengetahui komponen yang harus dilakukan perawatan dan menurunkan downtime pada mesin tersebut (Hidayah \& Ahmadi, 2017). Strategi perawatan mesin dengan metode Maintenance Value Stream Map (MVSM) dapat menentukan komponen yang tidak perlu dirawat pada mesin Heavy Duty Hammer Shredder (HDS) (Huda et al., 2014). Metode pemilihan prioritas perawatan mesin yang lainnya yaitu Analytic Hierarchy Process (AHP) (Bevilacqua \& Braglia, 2000). Penggunaan AHP dalam pemilihan strategi perawatan mesin di industri migas dapat 
mengurangi biaya perawatan dan meningkatkan kesiapan komponen mesin (Mostafa \& Fahmy, 2020).

Failure Mode and Effect Analysis (FMEA) merupakan salah satu metode mengevaluasi risiko pada sistem. FMEA dapat mengevaluasi dan menganalisis komponen pada sistem sehingga dapat meminimalkan risiko atau efek dari suatu tingkat kegagalan sebagai metode pendukung penilaian performansi pada suatu sistem (Imanuell \& Lutfi, 2019). Peranan metode FMEA sendiri dapat digunakan untuk mengetahui risiko kecelakaan pada sistem (Sukwadi et al., 2017), risiko kegagalan produksi komponen (Hasbullah et al., 2017), risiko sistem rantai pasok (Liu et al., 2018) dan lain sebagainya. Penelitian tentang analisa perawatan dengan mendeteksi risiko kegagalan pada mesin atau alat dapat digunakan dengan metode FMEA. Hasilnya dapat memperoleh tiga komponen penting yang harus di prioritaskan dalam perawatannya yaitu pada stick cylinder, penyaring bahan bakar dan oil pan (Darmawan et al., 2017). Penelitian lain yang membahas tentang analisis perawatan mesin pada sebuah agro-industri menggunakan metode FMEA. Hasilnya yaitu mendapatkan tiga klasifikasi kategori untuk melakukan perawatan (Soewardi \& Wulandari, 2019). Penggunaan metode FMEA selain di mesin industri banyak digunakan juga untuk menganalisis perencanaan perawatan preventif pada mesin dikapal. Hasilnya metode FMEA dapat mengidentifikasi prioritas dari komponen stainer penjadi paling tinggi nilai RPN (Risk Priority Number) dibandingkan komponen lainnya (Cicek et al., 2010).

Berdasarkan paparan di atas maka perlu adanya metode untuk menentukan pemilihan atau prioritas pada perawatan komponen sistem bahan bakar pada mesin induk. Tujuan pada penelitian ini yaitu untuk mengidentifikasi komponen pada sistem bahan bakar pada mesin induk yang memiliki nilai kritis berdasarkan perhitungan FMEA sehingga dapat dijadikan prioritas pada perawatan.

\section{Metodologi}

Pembuatan analisis perawatan berbasis risiko dengan metode FMEA memiliki beberapa langkah yang menggambarkan identifikasi dan evaluasi dari sistem, proses serta perawatan untuk menentukan strategi perawatan hasil dari metode tersebut. Penentuan objek dari penelitian ini yaitu sistem bahan bakar pada mesin induk pada KM. Sidomulyo di PPS Sibolga, Sumatera Utara. Mesin induk pada Kapal Motor tersebut memiliki spesifikasi yang di tunjukkan pada Tabel 1. Pembuatan definisi sistem bahan bakar disusun berdasarkan PID Block diagram diperoleh dari hasil PID komponen yang terpasang dengan disesuaikan dengan gambar PID manual mesin induk kapal. Penentuan definisi proses dan studi kejadian tiap komponen sistem bahan bakar mesin induk disusun dari studi referensi pada artikel yang dicocokkan dengan data lapangan. Data lapangan dapat dilihat pada data instrumen yang terpasang pada mesin atau buku manual mesin.

Tabel 1. Spesifikasi mesin induk

\begin{tabular}{|l|l|}
\hline \multicolumn{1}{|c|}{ Tipe mesin } & $\begin{array}{c}\text { 4 langkah, } \mathbf{9 0}^{\mathbf{}} \text { type } \\
\text { V10 }\end{array}$ \\
\hline Jenis Raung Bakar & Direct fuel injection \\
\hline Volume Siliner & $18.894 \mathrm{~cm}^{3}$ \\
\hline Perbandingan Kompresi & $17.3: 1$ \\
\hline Tekanan Kompresi 200rpm & $31 \mathrm{~kg} / \mathrm{cm}^{3}$ \\
\hline Putaran Stasioner & $450-500 \mathrm{rpm}$ \\
\hline Celah Katup Hisap & $0,4 \mathrm{~mm}$ \\
\hline Celah Katup Buang & $0,6 \mathrm{~mm}$ \\
\hline Tipe Governor & Centrifugal \\
\hline Jenis Injector & 5 lubang \\
\hline Tekanan Awal Injector & $180-220 \mathrm{~kg} / \mathrm{cm}^{2}$ \\
\hline Daya Mesin & $380 \mathrm{PK}$ \\
\hline
\end{tabular}

Pengumpulan data dengan cara studi literatur dan survei interview berupa jenis kerusakan, mekanisme kegagalan, pengaruh kegagalan, cara mendeteksi kegagalan, tingkat keparahan (severty), tingkat terjadi (occurance) dan tingkat kesulitan pendeteksian (detection) serta cara perawatan yang dilakukan. Proses survei dilakukan dengan mewawancarai Nakhoda, Kepala Kamar Mesin atau pekerja yang memiliki pengalaman pada mesin induk kapal. Proses survei ini dilakukan dengan cara narasumber menjawab pertanyaan pada kuesioner yang memiliki standar dalam beberapa skala yang sudah disiapkan.

Penilaian risiko dengan metode FMEA dapat menggunakan skala nilai kualitatif dengan mengidentifikasi beberapa kriteria yang sudah ditentukan. Penilaian tersebut dapat mengoptimalkan rencana perawatan (ArabianHoseynabadi et al., 2010) pada mesin induk kapal. Metode tersebut pada penelitian ini digunakan untuk mengidentifikasi parameter yang ada pada FMEA, antara lain (Priharanto et al., 2017; Surya et al., 2017): 
a. Tingkat keparahan bahaya yang ditunjukkan pada severity (S) yaitu bagaimana keseriusan bahaya ketika sistem bekerja. Skala Keparahan (severity) ditunjukkan pada Tabel 2.

Tabel 2. Tingkat keparahan kegagalan dan kriteria tingkat bahayanya

\begin{tabular}{|c|c|c|}
\hline $\begin{array}{l}\text { Tingkat } \\
\text { bahaya }\end{array}$ & Kriteria & Tingkat \\
\hline $\begin{array}{l}\text { Sangat } \\
\text { Berbahaya } \\
\text { Sekali }\end{array}$ & $\begin{array}{c}\text { Kerusakan komponen } \\
\text { menyebabkan kecelakaan } \\
\text { secara tiba-tiba dan } \\
\text { membahayakan keselamatan } \\
\text { kerja }\end{array}$ & 10 \\
\hline $\begin{array}{c}\text { Sangat } \\
\text { Berbahaya }\end{array}$ & $\begin{array}{c}\text { Kerusakan komponen } \\
\text { menyebabkan kecelakaan } \\
\text { kerja dan mesin tidak } \\
\text { beroperasi namun ada } \\
\text { peringatan/pendeteksian dini }\end{array}$ & 9 \\
\hline $\begin{array}{l}\text { Sangat } \\
\text { Tinggi }\end{array}$ & $\begin{array}{c}\text { Kerusakan komponen } \\
\text { mengakibatkan mesin mati } \\
\text { dan kehilangan fungsi } \\
\text { utamanya }\end{array}$ & 8 \\
\hline Tinggi & $\begin{array}{c}\text { Kerusakan komponen } \\
\text { mengakibatkan sistem mati } \\
\text { namun mesin masih } \\
\text { beroperasi }\end{array}$ & 7 \\
\hline Moderat & $\begin{array}{l}\text { Kerusakan komponen } \\
\text { mengakibatkan kinerja sistem } \\
\text { menurun drastis namun } \\
\text { mesin masih dapat } \\
\text { beroperasi }\end{array}$ & 6 \\
\hline Rendah & $\begin{array}{c}\text { Kerusakan komponen } \\
\text { mengakibatkan kinerja sistem } \\
\text { menurun secara bertahap } \\
\text { dengan mesin masih dapat } \\
\text { beroperasi }\end{array}$ & 5 \\
\hline $\begin{array}{l}\text { Sangat } \\
\text { Rendah }\end{array}$ & $\begin{array}{l}\text { Kerusakan komponen } \\
\text { mengakibatkan pengaruh } \\
\text { kecil pada kinerja sistem } \\
\text { dengan mesin masih } \\
\text { beroperasi sempurna }\end{array}$ & 4 \\
\hline Kecil & $\begin{array}{c}\text { Komponen mengalami kinerja } \\
\text { menurun namun sistem } \\
\text { bahan bakar dan mesin } \\
\text { masih berjalan sempurna }\end{array}$ & 3 \\
\hline $\begin{array}{c}\text { Sangat } \\
\text { Kecil }\end{array}$ & $\begin{array}{l}\text { Komponen dipandang buruk } \\
\text { namun kinerja komponen } \\
\text { masih baik dan sistem serta } \\
\text { mesin masih berjalan } \\
\text { sempurna }\end{array}$ & 2 \\
\hline Tidak Ada & Tidak ada pengaruh & 1 \\
\hline
\end{tabular}

b. Frekuensi Terjadi yang ditunjukkan pada Occurance (O) yaitu seberapa banyak kejadian gangguan pada komponen sehingga menyebabkan sistem terjadi kegagalan atau dapat disebut adanya peluang terjadinya munculnya gangguan. Skala Terjadi (Occurance) ditunjukkan pada Tabel 3.

c. Tingkat Deteksi yang ditunjukkan pada Detection (D) yaitu bagaimana kegagalan dapat diidentifikasi sebelum/tepat sebelum kejadian terjadi. Penilaian sangat subjektif dan tergantung pengalaman dari narasumber lapangan. Skala Deteksi (Detection) ditunjukkan pada Tabel 4.

Tabel 3. Tingkat terjadi kegagalan dan jumlah kejadian

\begin{tabular}{|c|c|c|}
\hline Tingkat terjadi & Jumlah kejadian & Tingkat \\
\hline $\begin{array}{l}\text { Sangat Sering } \\
\text { terjadi hingga } \\
\text { kerusakan tidak } \\
\text { bisa dihindari }\end{array}$ & $\begin{array}{l}\text { Hampir setiap saat } \\
\text { terjadi dalam waktu } \\
\text { kurang dari } 1-2 \text { kali } \\
\text { operasi }\end{array}$ & 10 \\
\hline $\begin{array}{c}\text { Sangat Sering } \\
\text { terjadi }\end{array}$ & $\begin{array}{l}\text { Sangat tinggi terjadi } \\
\text { dalam waktu kurang } \\
\text { dari 3-4 kali operasi }\end{array}$ & 9 \\
\hline $\begin{array}{l}\text { Sering terjadi } \\
\text { (1) }\end{array}$ & $\begin{array}{c}\text { Tinggi terjadi dalam } \\
\text { waktu kurang dari 5-8 } \\
\text { kali operasi }\end{array}$ & 8 \\
\hline $\begin{array}{l}\text { Sering terjadi } \\
\text { (2) }\end{array}$ & $\begin{array}{c}\text { Cukup tinggi dalam } \\
\text { waktu kurang dari 9-20 } \\
\text { kali operasi }\end{array}$ & 7 \\
\hline $\begin{array}{c}\text { Jarang terjadi } \\
\text { (1) }\end{array}$ & $\begin{array}{l}\text { Menengah terjadi dalam } \\
\text { waktu kurang dari 21-80 } \\
\text { kali operasi }\end{array}$ & 6 \\
\hline $\begin{array}{c}\text { Jarang terjadi } \\
\text { (2) }\end{array}$ & $\begin{array}{l}\text { Rendah terjadi dalam } \\
\text { waktu kurang dari } 81- \\
400 \text { kali operasi }\end{array}$ & 5 \\
\hline $\begin{array}{c}\text { Jarang terjadi } \\
\text { (3) }\end{array}$ & $\begin{array}{l}\text { Jarang terjadi dalam } \\
\text { waktu kurang dari 401- } \\
2000 \text { kali operasi }\end{array}$ & 4 \\
\hline $\begin{array}{c}\text { Sangat jarang } \\
\text { terjadi (1) }\end{array}$ & $\begin{array}{c}\text { Sangat jarang dalam } \\
\text { waktu kurang dari 2001- } \\
15000 \text { kali operasi }\end{array}$ & 3 \\
\hline $\begin{array}{c}\text { Sangat jarang } \\
\text { terjadi (2) }\end{array}$ & $\begin{array}{l}\text { Hamper tidak pernah } \\
\text { dalam waktu lebih dari } \\
15001 \text { kali operasi }\end{array}$ & 2 \\
\hline $\begin{array}{c}\text { Tidak pernah } \\
\text { terjadi }\end{array}$ & Tidak pernah terjadi & 1 \\
\hline
\end{tabular}

RPN (Risk Priority Number) merupakan hasil gabungan dari tiga variabel yang meliputi severity (S), Occurance (O) dan Detection (D) atau dapat menggunakan persamaan:

$\mathrm{RPN}=\mathrm{S} \times \mathrm{O} \times \mathrm{D}$

Pers. 1

Struktur umum parameter indeks resiko dan matriks RPN digunakan untuk pengumpulan data dari hasil dari penilaian (Balaraju, Govinda and Murthy, 2019). Struktur parameter indeks risiko dan matriks RPN dapat ditunjukkan pada Tabel 5.

Penilaian RPN ditetapkan dengan skala kuantitatif dari hasil penafsiran skala kualitatif. RPN memberikan informasi untuk menentukan prioritas potensi kegagalan pada komponen. Penentuan prioritas perawatan komponen ditentukan dari nilai RPN komponen yang berada di atas ambang batas nilai RPN keseluruhan. Nilai ambang batas RPN sistem diperoleh dari rata-rata nilai RPN pada semua komponen. 
Tabel 4. Tingkat deteksi kegagalan dan kriteria tingkat deteksinya

\begin{tabular}{|c|c|c|}
\hline Deteksi & Kriteria & Tingkat \\
\hline $\begin{array}{l}\text { Mustahil untuk } \\
\text { terdeteksi }\end{array}$ & $\begin{array}{l}\text { Tidak akan terkontrol } \\
\text { dan/atau terdeteksi } \\
\text { adanya penyebab } \\
\text { potensi kegagalan } \\
\text { serta kerusakan } \\
\text { selanjutnya }\end{array}$ & 10 \\
\hline $\begin{array}{c}\text { Sangat sulit } \\
\text { untuk terdeteksi }\end{array}$ & $\begin{array}{c}\text { Sangat sulit untuk } \\
\text { mengontrol perubahan } \\
\text { untuk mendeteksi } \\
\text { penyebab potensi dan } \\
\text { jenis kegagalan } \\
\text { selanjutnya }\end{array}$ & 9 \\
\hline $\begin{array}{l}\text { Sulit untuk } \\
\text { terdeteksi }\end{array}$ & $\begin{array}{l}\text { Sulit untuk mengontrol } \\
\text { perubahan untuk } \\
\text { mendeteksi penyebab } \\
\text { potensi dan jenis } \\
\text { kegagalan selanjutnya }\end{array}$ & 8 \\
\hline $\begin{array}{l}\text { Untuk terdeteksi } \\
\text { sangat rendah }\end{array}$ & $\begin{array}{l}\text { Sangat rendah untuk } \\
\text { mendeteksi penyebab } \\
\text { potensi dan jenis } \\
\text { kegagalan selanjutnya }\end{array}$ & 7 \\
\hline $\begin{array}{l}\text { Untuk terdeteksi } \\
\text { rendah }\end{array}$ & $\begin{array}{c}\text { Rendah untuk } \\
\text { mendeteksi penyebab } \\
\text { potensi dan jenis } \\
\text { kegagalan selanjutnya }\end{array}$ & 6 \\
\hline $\begin{array}{c}\text { Untuk terdeteksi } \\
\text { sedang }\end{array}$ & $\begin{array}{l}\text { Hampir tidak mudah } \\
\text { untuk mendeteksi } \\
\text { penyebab potensi dan } \\
\text { jenis kegagalan } \\
\text { selanjutnya }\end{array}$ & 5 \\
\hline $\begin{array}{l}\text { Untuk terdeteksi } \\
\text { menengah ke } \\
\text { atas }\end{array}$ & $\begin{array}{l}\text { Hampir mudah untuk } \\
\text { mendeteksi penyebab } \\
\text { potensi dan jenis } \\
\text { kegagalan selanjutnya }\end{array}$ & 4 \\
\hline $\begin{array}{c}\text { Mudah untuk } \\
\text { mendeteksi }\end{array}$ & $\begin{array}{c}\text { Mudah terkontrol untuk } \\
\text { mendeteksi penyebab } \\
\text { potensi dan jenis } \\
\text { kegagalan selanjutnya }\end{array}$ & 3 \\
\hline $\begin{array}{l}\text { Sangat mudah } \\
\text { untuk terdeteksi }\end{array}$ & $\begin{array}{c}\text { Sangat mudah } \\
\text { terkontrol untuk } \\
\text { mendeteksi penyebab } \\
\text { potensi dan jenis } \\
\text { kegagalan selanjutnya }\end{array}$ & 2 \\
\hline $\begin{array}{l}\text { Deteksi dapat } \\
\text { dilakukan } \\
\text { dengan } \\
\text { mudah/kasat } \\
\text { mata }\end{array}$ & $\begin{array}{c}\text { Dapat diduga akan } \\
\text { seringnya terjadi } \\
\text { mengakibatkan deteksi } \\
\text { pada potensi penyebab } \\
\text { dan kejadian }\end{array}$ & 1 \\
\hline
\end{tabular}

Tabel 5. Matriks pengisian parameter indeks resiko dan RPN

\begin{tabular}{|l|c|c|c|c|}
\hline \multicolumn{1}{|c|}{ Komponen } & S & O & D & RPN \\
\hline Tangki bahan bakar & $\mathrm{X}_{11}$ & $\mathrm{X}_{12}$ & $\mathrm{X}_{13}$ & $\mathrm{RPN}_{1}$ \\
\hline Separator & $\mathrm{X}_{21}$ & $\mathrm{X}_{22}$ & $\mathrm{X}_{23}$ & $\mathrm{RPN}_{2}$ \\
\hline $\begin{array}{l}\text { Pompa distribusi } \\
\text { bahan bakar }\end{array}$ & $\mathrm{X}_{31}$ & $\mathrm{X}_{32}$ & $\mathrm{X}_{33}$ & $\mathrm{RPN}_{3}$ \\
\hline $\begin{array}{l}\text { Saringan bahan } \\
\text { Bakar }\end{array}$ & $\mathrm{X}_{41}$ & $\mathrm{X}_{42}$ & $\mathrm{X}_{43}$ & $\mathrm{RPN}_{4}$ \\
\hline Pompa injeksi & $\mathrm{X}_{51}$ & $\mathrm{X}_{52}$ & $\mathrm{X}_{53}$ & $\mathrm{RPN}_{5}$ \\
\hline Injektor & $\mathrm{X}_{61}$ & $\mathrm{X}_{62}$ & $\mathrm{X}_{63}$ & $\mathrm{RPN}_{6}$ \\
\hline
\end{tabular}

Diagram pareto merupakan sebuah histogram yang digunakan untuk membantu menentukan area yang paling kritis pada suatu sistem. Penentuan area kritis pada diagram pareto diidentifikasi dari $20 \%$ adalah jenis kegagalan yang merupakan $80 \%$ kegagalan dari keseluruhan sistem. Diagram pareto digunakan untuk membantu analisa penentuan komponen prioritas perawatan berdasarkan komponen yang dianggap kritis.

\section{Hasil dan Diskusi}

Berdasarkan studi kasus dan survei lapangan yang dilakukan di KM. Sidomulyo terdapat PID sistem bahan bakar yang ada pada dokumen mesin induk KM. Sidomulyo. Selanjutnya validasi sistem bahan bakar pada kamar mesin untuk memastikan komponen pada PID sesuai dengan yang terpasang pada mesin induk. Hasil dari validasi dan studi literatur menunjukkan bahwa pada sistem bahan bakar mesin induk KM. Sidomulyo memiliki komponen utama antara lain Tangki Bahan Bakar, Separator, Pompa Distribusi Bahan Bakar, Saringan Bahan Bakar, Pompa Injeksi serta Pompa Injektor (Saputra et al., 2018).

Penyusunan proses sistem bahan bakar KM. Sidomulyo digambarkan menggunakan diagram blok pada Gambar 1. Gambar diagram blok tersebut dapat menjadi acuan sebagai batasan sistem untuk menganalisis risiko kegagalan pada sistem bahan bakar mesin induk dengan metode FMEA (Priharanto et al., 2017).

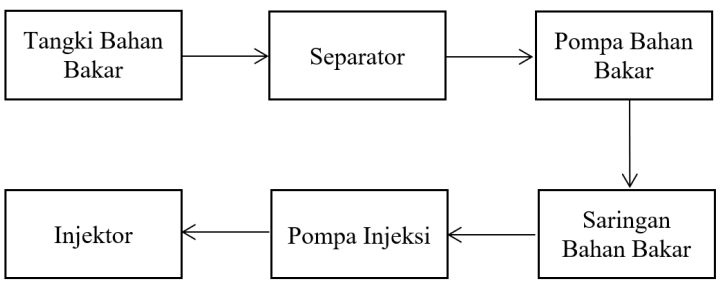

Gambar 1. Diagram blok sistem bahan bakar mesin induk KM. Sidomulyo

Hasil dari validasi studi literatur dan survei lapangan dengan metode Failure Mode and Effect Analysis (FMEA) sistem bahan bakar ditunjukkan pada Tabel 6 (Alwi, 2016; Cicek et al., 2010; Hadi \& Untung, 2008; Imanuell \& Lutfi, 2019; Islam et al., 2019; Saputra et al., 2018). Berdasarkan identifikasi tabel FMEA menjelaskan adanya fungsi dari setiap komponen, jenis kegagalan setiap komponen, mekanisme kegagalan yang terjadi, pengaruh terjadinya kegagalan (Setiawan \& Iwan, 2014) pada sistem maupun mesin induk, cara 
mendeteksi kegagalan dan saran untuk mengurangi kejadian kegagalan pada setiap komponen sistem bahan bakar. Hasil dari analisa potensial beberapa kegagalan pada komponen sistem bahan bakar tersebut menjadikan dasar untuk penilaian RPN.

Hasil dari pendekatan FMEA pada Tabel 7 memberikan informasi kemungkinan terjadi kegagalan pada tiap komponen sistem bahan bakar seiring dengan nilai RPN yang identik diperoleh dari hasil tersebut. Secara umum, dapat diasumsikan bahwa semua parameter indeks risiko memiliki peran yang sama dalam penentuan prioritas. Nilai RPN pada Tabel 6 yang memiliki jumlah mode kegagalan yang sama di setiap komponennya maka dapat diperkirakan dengan persamaan berikut (Balaraju et al., 2019):

$$
R P N=\prod_{i, j=1}^{n} X_{i j}
$$

Pers. 2

Di mana $\mathrm{n}$ adalah nilai dari jumlah jenis kegagalan yang terjadi pada setiap komponen, sedangkan $1 \leq \mathrm{i} \leq \mathrm{n}$ dan $1 \leq \mathrm{j} \leq \mathrm{n}$ serta nilai dari $\mathrm{X}_{\mathrm{ij}}$ dapat identifikasi dari letak $\mathrm{S}, \mathrm{O}, \mathrm{D}$ dari tiap komponen yang memiliki mode kegagalan ( $\mathrm{i}=$ $1,2,3$, dst dan $j=1,2,3$, dst). Nilai $X_{i j}$ secara akurat pada skala interval 1 hingga 10 . Skala tersebut dapat ditunjukkan pada matriks yang telah disediakan pada Tabel 5 serta hasil dari pengisian interval tersebut di tunjukkan pada Tabel 6 .

Gambar 2 dan Tabel 7 menunjukkan nilai RPN setiap komponen yang ada pada sistem bahan bakar mesin induk KM. Sidomulyo. Hasil dari perhitungan menunjukkan bahwa komponen injektor memiliki nilai tertinggi pada perhitungan RPN yaitu sebesar 192. Hasil perhitungan RPN injektor dengan nilai Severity 6 menyatakan jika terjadi kegagalan maka kinerja sistem akan menurun, nilai Occurance 4 menyatakan terjadinya mode kegagalan setelah sistem beroperasi kurang dari 401-2000 kali operasi. Nilai detection 8 menyatakan tingkat kesulitan mendeteksi dan mengontrol jika terjadi kegagalan pada komponen tersebut. Nilai RPN komponen injektor sangat berbeda dengan perolehan nilai yang dihasilkan komponen saringan bahan bakar (RPN 168). Berdasarkan penelitian sebelumnya komponen bahan bakar merupakan salah satu komponen yang perlu dirawat karena memiliki nilai tingkat terjadi kegagalan yang tertinggi (Saputra et al., 2018). Komponen injektor memiliki nilai RPN yang tinggi dikarenakan memiliki tingkat occruance dan tingkat detection yang tinggi dari pada komponen lainya. Walaupun injektor memiliki tingkat severity yang rendah, namun nilai RPN komponen injektor masih paling tinggi. Hal tersebut menguatkan secara teori bahwa nilai RPN sangat bergantung terhadap tiga parameter yaitu severity, occurance dan detection (Priharanto et al., 2017).

Tabel 7. Nilai dari parameter indeks risiko dan matriks RPN

\begin{tabular}{|c|l|c|c|c|c|}
\hline No & Komponen & S & O & D & RPN \\
\hline 1 & Tangki bahan bakar & 8 & 1 & 4 & 32 \\
\hline 2 & Separator & 5 & 4 & 4 & 80 \\
\hline 3 & $\begin{array}{l}\text { Pompa distribusi } \\
\text { bahan bakar }\end{array}$ & 3 & 3 & 7 & 63 \\
\hline 4 & Saringan bahan bakar & 6 & 4 & 7 & 168 \\
\hline 5 & Pompa Injeksi & 6 & 2 & 7 & 84 \\
\hline 6 & Injektor & 6 & 4 & 8 & 192 \\
\hline
\end{tabular}

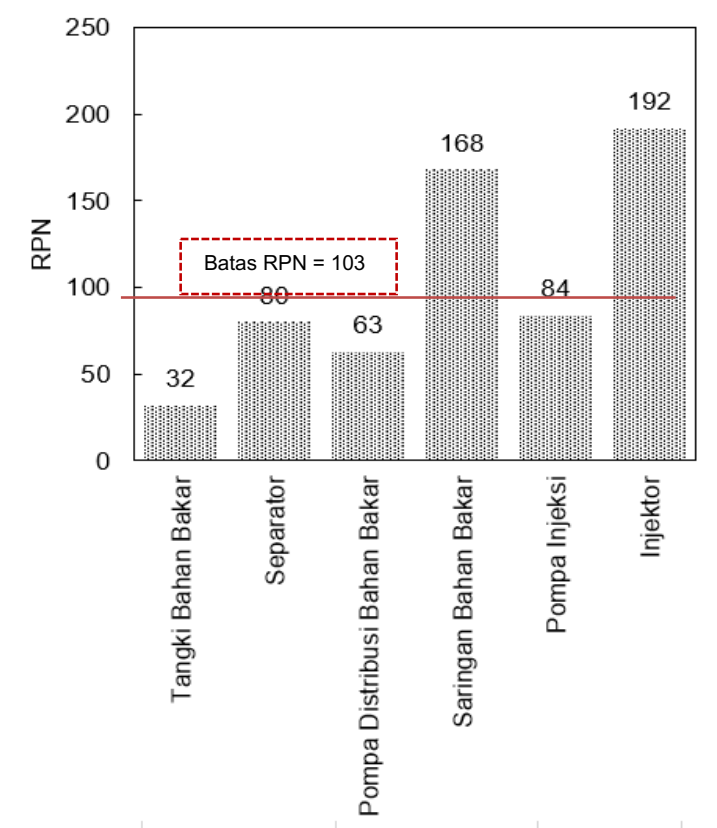

Gambar 2. Diagram prioritas penanganan kegagalan komponen

Nilai RPN sangat mempengaruhi pemilihan strategi perawatan/pemeliharaan yang tepat berdasarkan kategori strategi pemeliharaan yang tergantung dari Nilai RPN. Nilai RPN pada persamaan 2 memiliki nilai pada rentang 1 sampai dengan 1000 . Tingkat risiko semakin tinggi tergantung dari Nilai RPN yang diperoleh sehingga nilai RPN sangat berhubungan dengan pemilihan strategi (Situngkir et al., 2019). Berdasarkan Tabel 7 dan Gambar 2, nilai RPN dari setiap mode kegagalan pada komponen sistem bahan bakar memiliki rentang 32 sampai dengan 192. 


\begin{tabular}{|c|c|c|c|c|c|c|}
\hline 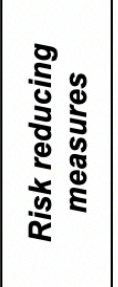 & 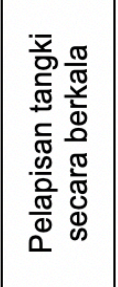 & 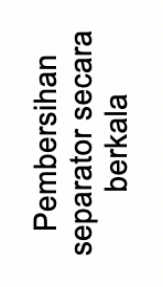 & 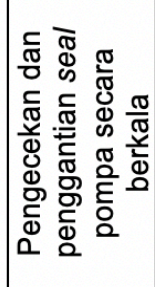 & 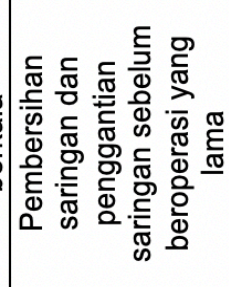 & 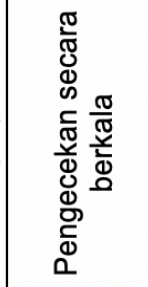 & 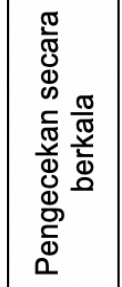 \\
\hline 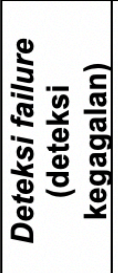 & 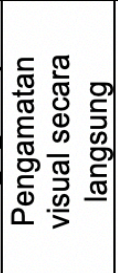 & 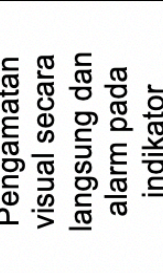 & 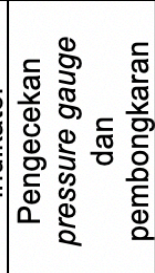 & 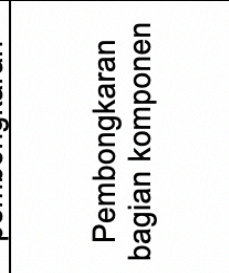 & 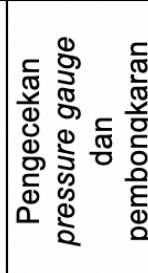 & 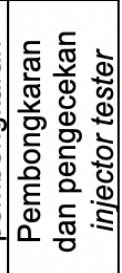 \\
\hline 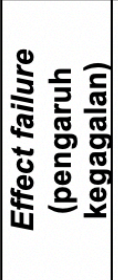 & 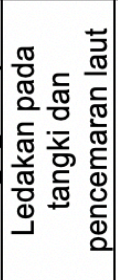 & 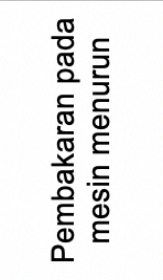 & 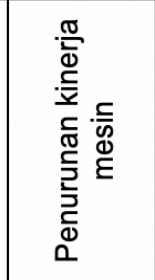 & 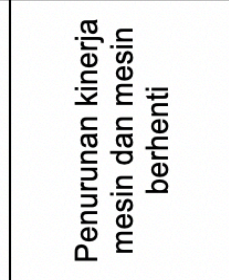 & 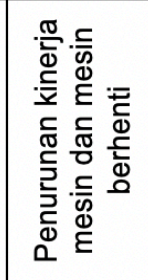 & 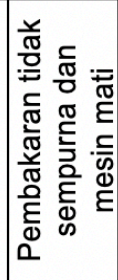 \\
\hline 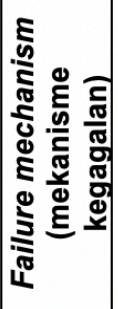 & 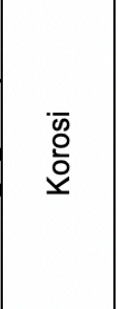 & 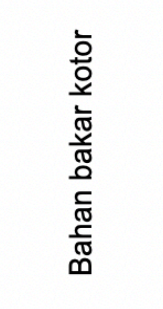 & 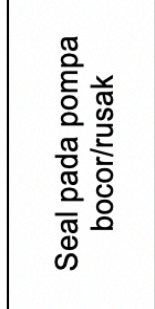 & 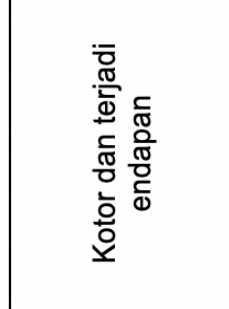 & 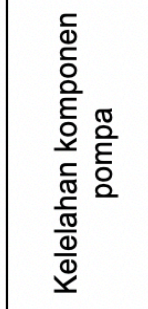 & 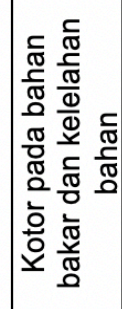 \\
\hline 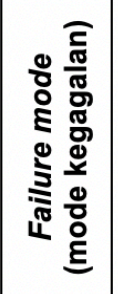 & 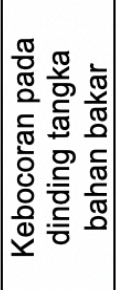 & 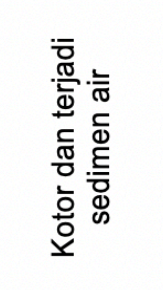 & 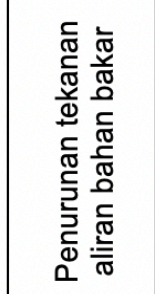 & 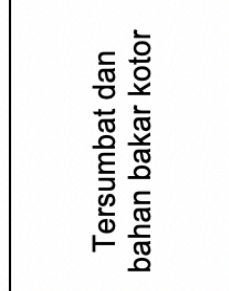 & 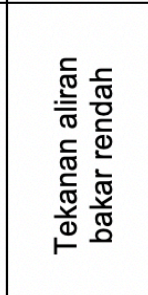 & 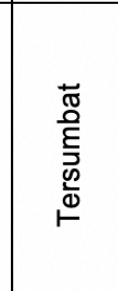 \\
\hline $\begin{array}{l}\bar{y} \\
\stackrel{\bar{g}}{\mathfrak{5}} \\
\overline{5}\end{array}$ & 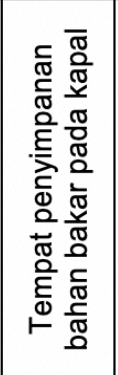 & 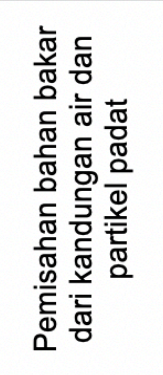 & 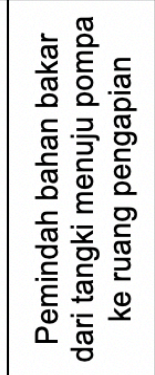 & 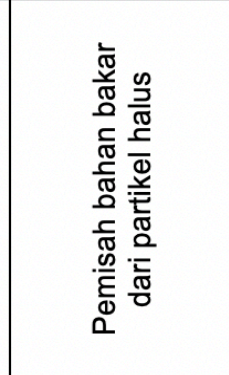 & 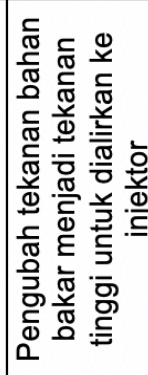 & 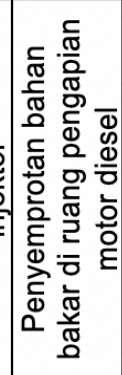 \\
\hline 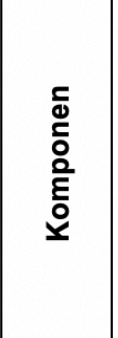 & 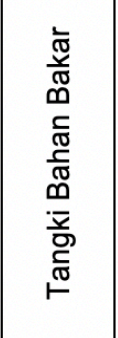 & 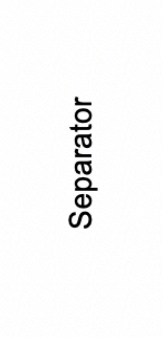 & 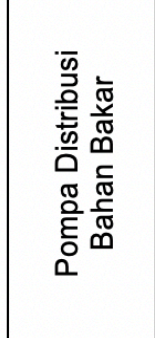 & 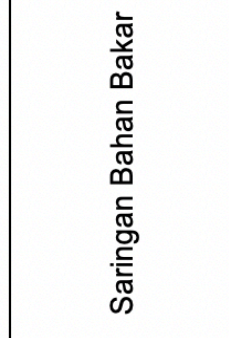 & 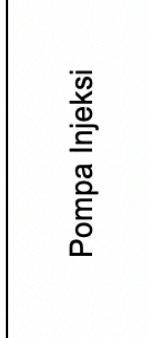 & 嵩 \\
\hline 을 & $\dot{r}$ & N & $\dot{m}$ & $\dot{\nabla}$ & $\omega^{\circ}$ & $\dot{0}$ \\
\hline
\end{tabular}


Berdasarkan Tabel 8 terdapat penjelasan mengenai strategi pemilihan perawatan yang sesuai untuk setiap komponen yaitu pemeliharaan korektif $(\mathrm{RPN}<200)$.

Tabel 8. Pemilihan kriteria untuk strategi pemeliharaan (Puthillath \& Sasikumar, 2012; Sahoo et al., 2014).

\begin{tabular}{|c|l|l|}
\hline Rank & Teknik Pemeliharaan & \multicolumn{1}{|c|}{ Kriteria } \\
\hline 1 & Pemeliharaan Prediktif & $\mathrm{RPN}>300$ \\
\hline 2 & Pemeliharaan Preventif & $200<\mathrm{RPN}<300$ \\
\hline 3 & Pemeliharaan Korektif & $\mathrm{RPN}<200$ \\
\hline
\end{tabular}

Berdasarkan Gambar 2 terdapat nilai ambang batas RPN yang telah dihitung dari semua komponen sistem bahan bakar mesin induk. Nilai ambang batas RPN tersebut sebesar 103. Nilai ambang batas RPN tersebut menjadi tolak ukur acuan prioritas pada komponen dengan membuat kategori nilai RPN komponen yang melebihi ambang batas tersebut (Suryaningrat, 2019). Nilai rata-rata tersebut merupakan batas untuk melakukan tindakan pencegahan dan perawatan pada komponen tersebut (Faturachman et al., 2014). Berdasarkan Gambar 2, komponen injektor (RPN 192) dan saringan bahan bakar (RPN 168) merupakan komponen yang memiliki prioritas perawatan dalam sistem bahan bakar mesin induk.

Berdasarkan diagram pareto pada Gambar 3, dapat diketahui jenis kegagalan pada sistem bahan bakar yang paling dominan dengan melihat kumulatif nya. Sesuai dengan prinsip pareto yang menyatakan $80 / 20$ di mana $80 \%$ masalah kegagalan disebabkan oleh 20\% penyebab kegagalan (Ramadhani et al., 2014) sehingga di pilih $80 \%$ dapat diasumsikan menjadikan permasalahan utama pada kegagalan sistem. Komponen yang masuk dalam $80 \%$ tersebut yaitu injektor (31\%), saringan bahan bakar (27\%) dan pompa injeksi (13\%). Ketiga komponen tersebut direkomendasikan untuk diprioritaskan dalam perawatan secara korektif dan berkala jika mengalami kegagalan sistem bahan bakar. Hal tersebut dikarenakan komponen yang termasuk dari $80 \%$ dari sistem tersebut jika diprioritaskan dilakukan penanganan (perawatan) maka semakin naik kualitas keandalan dari sistem bahan bakar mesin induk (Gunawan \& Tannady, 2016).

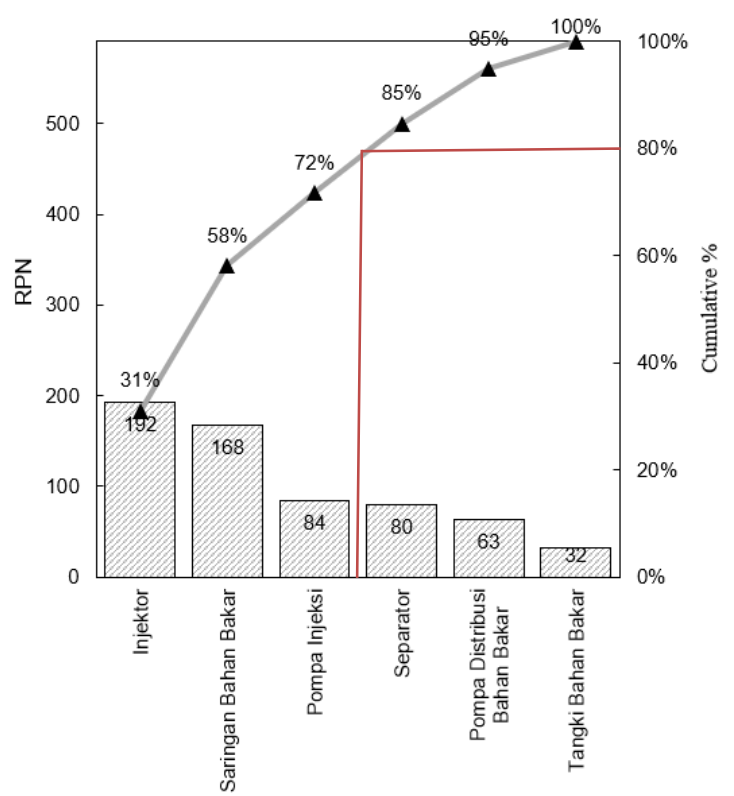

Gambar 3. Diagram paretto RPN sistem bahan bakar mesin induk KM. Sidomulyo.

Komponen yang perlu tindakan perawatan yaitu komponen injektor dan saringan bahan bakar karena kedua komponen tersebut berada pada posisi melewati batas kritis RPN dan posisi kritis di diagram pareto. Komponen injektor memiliki kegagalan yang disebabkan karena bahan bakar yang kotor dan terjadi kelelahan bahan dari komponen penyusun injektor (Wilastari \& Puryadi, 2017). Pendeteksian dari komponen tersebut sangat sulit karena harus diperiksa menggunakan alat khusus.

Langkah alternatif ketika pengoperasian mesin induk yaitu kepala kamar mesin selalu membawa cadangan injektor sebelum berlayar untuk mengatasi jika injektor mengalami kegagalan ketika berlayar (Saputra et al., 2018). Komponen injektor sendiri sangat berperan vital pada pengoperasian mesin induk. Jika terjadi kerusakan pada injektor maka kinerja mesin akan menurun dan kapal tidak bekerja optimal karena mesin penggerak tidak optimal. Langkah mitigasi yang dapat dilakukan yaitu pengecekan komponen injektor saat akan beroperasi. Selain komponen injektor, komponen saringan bahan bakar juga harus ada perhatian kusus pada perawatan sistem bahan bakar mesin induk karena nilai RPN-nya juga melewati ambang batas dan berada di posisi kritis pada diagram pareto. Komponen saringan bahan bakar sendiri memiliki kegagalan yaitu tersumbat (Fathoni \& Hakim, 2019) dikarenakan endapan partikel 
padat. Walaupun bahan bakar sudah dipisahkan oleh separator dahulu tetapi partikel halus dapat melewati proses separator sehingga saringan sering kotor yang menyebabkan saringan tersumbat. Beberapa periode perawatan sebelum beroperasi komponen saringan bahan bakar menjadi perhatian wajib. Perawatan yang dilakukan pada saringan yaitu pembersihan deposit/endapan di sekitar dinding saringan (Saputra et al., 2018). Selain itu jika dirasa kondisi saringan sudah tidak layak maka dapat menggunakan cadangan yang selalu dibawa oleh Kepala Kamar Mesin. Tindakan mitigasi yang perlu dilakukan berupa pemeriksaan rutin dan perawatan khusus pada komponen yang memiliki RPN di atas ambang batas (Priharanto et al., 2017).

Komponen yang memiliki nilai RPN di bawah ambang batas dan termasuk daerah 20\% pareto tetap dilakukan perawatan. Hal tersebut dikarenakan beberapa komponen dapat menyebabkan mesin gagal beroperasi. Perawatan yang sering dilakukan yaitu perawatan setelah beroperasi yang dilakukan pada bengkel kapal darat atau dok (Saputra et al., 2018). Hal tersebut untuk mencegah kegagalan di luar prediksi dari penilaian.

\section{Kesimpulan}

Berdasarkan pembahasan di atas perawatan yang harus dilakukan pada komponen sistem bahan bakar mesin induk KM. Sidomulyo yaitu komponen injektor dan saringan bahan bakar. Komponen tersebut berturut-turut memiliki nilai RPN sebesar 192 dan 168. Kedua komponen tersebut diprioritaskan karena melewati batas kritis dari RPN Sistem bahan bakar serta termasuk pada komponen yang harus diprioritaskan menurut diagram pareto. Tindakan perawatan pada komponen injektor yaitu pemeriksaan secara rutin sebelum beroperasi dan perawatan khusus dengan memperhatikan kemurnian bahan bakar yang masuk pada sistem bahan bakar mesin induk. Sedangkan tindakan perawatan komponen saringan bahan bakar yaitu pembersihan partikel padat yang secara rutin. Tindakan perawatan pada komponen yang kritis dapat mengurangi resiko kegagalan pada sistem bahan bakar mesin induk.

\section{Daftar Pustaka}

Alhaddad, S. H., \& Dianta, mustofa K. (2015). Studi Kasus Pembakaran Tidak Sempurna pada Mesin Diesel tipe mak 8m 551ak milik pt . xxx. Seminar Nasional Teknik Mesin, 453-455.

Alwi, M. R. (2016). Reliability Centered Maintenance Dalam Perawatan. Jurnal Riset Dan Teknologi Kelautan (JRTK), 14(1), 77-86.

Amry, R. A., Renta, P. P., \& Nofridiansyah, E. (2017). Analisa Kelayakan Usaha Penangkapan Ikan Menggunakan Alat Tangkap Payang (Seine Net) Menggunakan Alat Bantu Rumpon Di Pantai Malabero Kota Bengkulu. Jurnal Enggano, 2(2), 129142.

Arabian-Hoseynabadi, H., Oraee, H., \& Tavner, P. J. (2010). Failure Modes and Effects Analysis (FMEA) for wind turbines. International Journal of Electrical Power and Energy Systems, 32(7), 817-824.

Artana, K. B., \& Ishida, K. (2002). Optimum Replacement and Maintenance Scheduling Process for Marine Machinery in Wear-Out Phase: A case Study on Main Engine Cooling Pumps. Journal of the Kansai Society of Naval Architects, 238, 173-184.

Awal, Z. I., \& Hasegawa, K. (2015). Analysis of Ship Accidents due to Marine Engine Failure - Application of Logic Programming Technique (LPT). Journal of The Japan Institute of Marine Engineering, 50(6), 744751.

Baharuddin. (2016). Perancangan Simulasi Kontrol Otomatis Distribusi Bahan Bakar Tangki Harian Pada KM. Madani Nusantara. Jurnal Riset Dan Teknologi Kelautan (JRTK), 14(1), 61-76.

Balaraju, J., Raj, M. G., \& Murthy, C. S. (2019). Fuzzy-FMEA risk evaluation approach for LHD machine-A case study. Journal of Sustainable Mining, 18(4), 257-268.

Bevilacqua, M., \& Braglia, M. (2000). Analytic Hierarchy Process Applied to Maintenance Strategy Selection. Reliability Engineering and System Safety, 70(1), 71-83.

Cicek, K., Turan, H. H., Topcu, Y. I., \& Searslan, M. N. (2010). Risk-based Preventive Maintenance Planning using Failure Mode and Effect Analysis (FMEA) for marine engine systems. 2nd International Conference on Engineering System 
Management and Applications, ICESMA.

Darmawan, A., Rapi, A., \& Ali, S. (2017). Analisis Perawatan Untuk Mendeteksi Risiko Kegagalan Komponen Pada Excavator 390D. Jurnal IImiah Teknik Industri, 15(2), 109.

Fathoni, A., \& Hakim, L. (2019). Penerapan Rcm Dengan Analisa Kualitatif (FMEA) Sebagai Studi Kegagalan Sistem Pembangkit (Genset) Pada Sebuah Hotel Bintang Empat Di Rokan Hulu. APTEK, 11(1), 69-77.

Faturachman, D., Mustafa, S., Octaviany, F., \& Novita, T. D. (2014). Failure Mode and Effects Analysis of Diesel Engine for Ship Navigation System Improvement. International Journal of Service Science, Management and Engineering, 1(1), 6-16.

Gunawan, C. V., \& Tannady, H. (2016). Analisis Kinerja Proses Dan Identifikasi Cacat Dominan Pada Pembuatan Bag Dengan Metode Statistical Proses Control (Studi Kasus: Pabrik Alat Kesehatan Pt.Xyz, Serang, Banten). J@Ti Undip : Jurnal Teknik Industri, 11(1), 9-14.

Hadi, E. S., \& Untung, B. (2008). Analisa Keandalan Sistem Bahan Bakar Motor Induk Pada Km. Leuser. Kapal, 5(2), 123-135.

Handani, D. W., \& Uchida, M. (2014). Modeling Optimum Operation of Ship Machinery by Using System Dynamics. Journal of The Japan Institute of Marine EngineeringMarine Engineering, 49(1), 132-141.

Hasbullah, H., Kholil, M., \& Santoso, D. A. (2017). Analisis Kegagalan Proses Insulasi Pada Produksi Automotive Wires (Aw) Dengan Metode Failure Mode and Effect Analysis (Fmea) Pada Pt Jlc. Sinergi, 21(3), 193.

Hidayah, N. Y., \& Ahmadi, N. (2017). Analisis Pemeliharaan Mesin Blowmould Dengan Metode RCM Di PT. CCAI. Jurnal Optimasi Sistem Industri, 16(2), 167.

Huda, A. T. N., Novareza, O., \& Andriani, D. P. (2014). Analisis Aktivitas Perawatan Mesin HDS di Stasiun Gilingan Menggunakan Maintenance Value Stream Map (MVSM) (Studi Kasus Pg. Kebon Agung Malang). Jurnal Rekayasa Dan Manajemen Sistem Industri, 3(2), 311-321.

Imanuell, R., \& Lutfi, M. (2019). Analisa Perawatan Berbasis Keandalan Pada Sistem Bahan Bakar Mesin Utama KMP.
Bontoharu. JST (Jurnal Sains Terapan), 5(1).

Islam, R., Anantharaman, M., Khan, F., \& Garaniya, V. (2019). Reliability Assessment of a Main Propulsion Engine Fuel Oil System-What are the Failure Prone Components? TransNav, 13(2), 415-420.

Kusdiantoro, K., Fahrudin, A., Wisudo, S. H., \& Juanda, B. (2019). Perikanan Tangkap Di Indonesia: Potret dan Tantangan Keberlanjutannya. Jurnal Sosial Ekonomi Kelautan Dan Perikanan, 14(2), 145.

Lasabuda, R. (2013). Pembangunan Wilayah Pesisir Dan Lautan Dalam Perspektif Negara Kepulauan Republik Indonesia. Jurnal IImiah Platax, I(2), 92-101.

Latif, M. Z., Priharanto, Y. E., Prasetyo, D., \& Muhfizar. (2018). Preliminary Hazard Analysis Dan Fault Tree Analysis Untuk Identifikasi Penyebab Kegagalan Sistem Pelumas Mesin Induk Kapal Penangkap Ikan. Airaha, 7(2), 77-87.

Liu, Y., Kong, Z., \& Zhang, Q. (2018). Failure Modes and Effects Analysis (FMEA) for the Security of the Supply Chain System of the Gas Station in China. Ecotoxicology and Environmental Safety, 164(5), 325-330.

Manalu, R. B., Budiarto, U., Yudo, H., Teknik, F., Diponegoro, U., \& Simulation, M. C. (2016). Analisa Perawatan Sistem Distribusi Minyak Lumas Berbasis Keandalan Pada Kapal Km.Bukit Siguntang Dengan Pendekatan RCM (Reliability Centered Maintenance). Jurnal Teknik Perkapalan, 4(1), 53-63.

Mostafa, M. F., \& Fahmy, S. A. (2020). Maintenance Strategy Selection Using AHP: A Case Study in the Oil and Gas Industry. 7th International Conference on Industrial Engineering and Applications, ICIEA, 10491053.

Nusantara, G. Y. (2015). Pengaruh Efek Perawatan Terhadap Jadwal Perawatan Sistem Pendukung Mesin Induk Pada Kapal Dengan Menggunakan Pemodelan Dinamik Sistem. In Jurusan Teknik Sistem Perkapalan, Institut Teknologi Sepuluh Nopember.

Priharanto, Y. E., Latif, M. Z., \& Saputra, R. S. H. (2017). Penilaian Risiko pada Mesin Pendingin di Kapal Penangkap Ikan Dengan Pendekatan FMEA. Jurnal Airaha, 6(1), 2432. 
Puthillath, B., \& Sasikumar, R. (2012). Selection of Maintenance Strategy Using Failure Mode Effect and Criticality Analysis. International Journal of Engineering and Innovative Technology (IJEIT), 1(6), 73-79.

Ramadhani, G. S., Yuciana, \& Suparti. (2014). Analisis Pengendalian Kualitas Menggunakan Diagram Kendali Demerit (Studi Kasus Produksi Air Minum Dalam Kemasan 240 Ml Di Pt Tiw). Jurnal Gaussian, 3(3), 401-410.

Sahoo, T., Sarkar, P. K., \& Sarkar, A. K. (2014). Maintenance Optimization for Critical Equipments in process industries based on FMECA Method. International Journal of Engineering and Innovative Technology (IJEIT), 3(10), 107-112.

Saputra, R. S. H., Priharanto, Y. E., \& Abrori, M. Z. L. (2018). Failure Mode and Effect Analysis (FMEA) Applied for Risk Assessment of Fuel Oil System on Diesel Engine of Fishing Vessel. ARPN Journal of Engineering and Applied Sciences, 13(21), 8414-8420.

Sasmita, S., Martasuganda, S., Purbayanto, A., \& Hestirianoto, T. (2013). Keselamatan Kerja pada Operasi Penangkapan Ikan Cantrang Nelayan Tanjung Sari, Kabupaten Rembang. Buletin PSP, 21(1), 11-17.

Setiawan, \& Iwan. (2014). Fmea Sebagai Alat Analisa Risiko Moda Kegagalan pada Magnetic Force Welding Machine Me-27.1. Pengelolaan Instalasi Nuklir, 13, 31-41.

Situngkir, D. I., Gultom, G., \& Tambunan, D. R. S. (2019). Pengaplikasian FMEA untuk Mendukung Pemilihan Strategi
Pemeliharaan pada Paper Machine. Flywheel : Jurnal Teknik Mesin, 5(2), 1-5.

Soewardi, H., \& Wulandari, S. A. (2019). Analysis of Machine Maintenance Processes by using FMEA Method in the Sugar Industry. IOP Conference Series: Materials Science and Engineering, 528(1), 0-7.

Sukwadi, R., Wenehenubun, F., \& Wenehenubun, T. W. (2017). Pendekatan Fuzzy FMEA dalam Analisis Faktor Risiko Kecelakaan Kerja. Jurnal Rekayasa Sistem Industri, 6(1), 29.

Surya, A., Agung, S., \& Charles, P. (2017). Penerapan Metode FMEA (Failure Mode And Effect Analysis) Untuk Kualifikasi Dan Pencegahan Resiko Akibat Terjadinya Lean Waste. Jurnal Online Poros Teknik Mesin, 6(1), 45-57.

Suryaningrat, D. (2019). Identifikasi Risiko pada Okra Menggunakan Failure Mode and Effect Analysis (FMEA) di PT. Mitratani Dua Tujuh Di Kabupaten Jember. Jurnal Agroteknologi, 13(1), 25-33.

Wannawiset, S., \& Tangjitsitcharoen, S. (2019). Paper Machine Breakdown Reduction by FMEA and Preventive Maintenance Improvement: a Case Study. IOP Conference Series: Materials Science and Engineering, 530(1).

Wilastari, S., \& Puryadi. (2017). Analisa Penyebab Terjadnya Kegagalan Pembakaran Awal Pada Ketel Uap Bantu. Majalah IImiah Gema Maritim, 19(1), 1-19. 
DOI: https://doi.org/10.26593/jrsi.v9i3.4075.189-200

Halaman ini sengaja dikosongkan.

This page is intentionally left blank. 